\title{
Effect of Playing Comprehension Model on Basketball Playing Skills
}

\author{
Lukmannul Haqim Lubay ${ }^{*}$, Amung Makmun, Tite Juliantine, Nuryadi \\ Department of Sports Education, School of Postgraduate Studies, Universitas Pendidikan Indonesia, Bandung, Indonesia
}

Received April 25, 2021; Revised June 15, 2021; Accepted July 15, 2021

\section{Cite This Paper in the following Citation Styles}

(a): [1] Lukmannul Haqim Lubay, Amung Makmun, Tite Juliantine, Nuryadi , "Effect of Playing Comprehension Model on Basketball Playing Skills, "International Journal of Human Movement and Sports Sciences, Vol. 9, No. 4A, pp. 15 - 19, 2021. DOI: 10.13189/saj.2021.091303.

(b): Lukmannul Haqim Lubay, Amung Makmun, Tite Juliantine, Nuryadi (2021). Effect of Playing Comprehension Model on Basketball Playing Skills. International Journal of Human Movement and Sports Sciences, 9(4A), 15 - 19. DOI: 10.13189/saj.2021.091303.

Copyright $\odot 2021$ by authors, all rights reserved. Authors agree that this article remains permanently open access under the terms of the Creative Commons Attribution License 4.0 International License

\begin{abstract}
The purpose of this study was to determine the effect of the application of the playing understanding training method on the performance of basketball athletes. This study used an experimental research method involving 40 basketball athletes aged 11-14 years in Bandung Regency as the study population. A sample of 20 people was tested for understanding playing through the instrument used was the Game Performance Assessment Instrument observation sheet. The sample taken was a group of athletes with early ability to play high basketball who were given the playing comprehension exercise method, the sampling technique used was saturated sampling with a one group - pretest - posttest design. The results of data processing and data analysis were obtained using the sample t-test, namely paired t-test. Based on the results of these calculations, the conclusion is that the method of understanding play can improve the performance of a group of athletes with high initial abilities to play basketball.
\end{abstract}

Keywords Playing Comprehension Training Method, High Initial Ability to Play Basketball, Athlete Performance, Basketball Game Activities

\section{Introduction}

Individual development is a socially organized pattern that is formed through the process of time, as well as changes in the surrounding environment [1]. In addition to time processes and environmental changes, increasing age will also affect cognitive, affective, and psychomotor development [2]. Individual development, both concerning the cognitive, affective, and psychomotor domains will specifically correspond to the stage or period of age [3]. Other studies say that individual development is divided into 6 (six) stages, namely (1) prenatal life at an age range of 0-8 weeks, (2) childhood at an age range of 1-10 years, (3) adolescence at an age range of 10-20 years, (4) adulthood at an age range of 20-60 years and more [4]. Lifelong individual development, especially at the age of children and adolescents, is dependent on the role of the world of education, both formally and informally. Meanwhile, in subsequent periods, it is highly dependent on the social interactions of these individuals in their respective environments.

The adolescence stage is the most vulnerable stage to children's growth and development physically, socially, and cognitively [5]. At this stage, physical and psychological development will experience changes, so it needs to be directed to positive activities, such as physical activities that can form the characteristics of self-confidence and optimism for the future [6]. The habit of doing physical activity in adolescence is depending on the early age. Physical activity carried out from an early age will provide benefits related to physical, social, and psychological health [7]. Youth participation in physical activity, carried out by teenagers after activities at school, is high. The results showed that the participation of 
adolescents in several sport activities was high, because they realized the benefits of physical activity on their quality of life [8]. The role of schools and sports clubs that routinely hold organized physical activity can stimulate interest in children and adolescents to participate in physical activity. Research shows that both schools and sports clubs can be used as a place for them to interact socially and explore their talents in sports [9]. In addition, through physical activity, both at school and in sports clubs, Physical Education teachers and coaches can see the giftedness of children to become athletes through programs and guidance at schools and sports clubs [10]. Talented athletes in the world of sports are closely related to the concept of Long Term Athlete Development or known as LTAD. This concept was adopted by North American countries related to the interaction of social life and was developed and applied to the field of sports [11]. The LTAD concept was developed in a gradual manner, which is to provide opportunities for every child, teenager, and adult to live a healthy life through physical activities.

Furthermore, this concept is used as gifted programs for young athletes to be able to achieve at a higher level. The LTAD concept has 5 stages, namely (1) fundamentals, (2) training to train, (3) training to compete, (4) training to win, (5) retirement / retaining [12]. Other research shows that the LTAD concept in basketball has the same stages as the LTAD concept developed by other researchers, namely the age of 6-10 years (Fun), the age of 11-14 years (Train), the age of 15-18 years (Competition), and 19 years and over (Win) [12]. However, in Indonesia, there are facts that reveal that some basketball clubs have different concepts, where most children aged 6-10 have been in the 'train' stage and at the age of 11-14 have been in the 'win' stage. This will have a negative impact that affects physical, psychological, and social development [14].

Referring to the LTAD concept and seeing the characteristics of basketball games that require physical conditions, such as running fast, stopping suddenly, throwing, and catching $[15,16]$. This game is suitable to be played by adolescents because there is an increase in the ability of physical activity, such as an increase in body size and weight, speed, endurance, agility, and strength [17]. In addition to physical conditions, basketball requires cooperative (affective) and cognitive factors. The ability to run while dribbling the ball, pass the ball to teammates, grab the ball, and put the ball into the opponent's ring are physical, cognitive, and cooperative (social) abilities that basketball players must have in order to win a match [18].

The description above shows that the problems that often arise in the context of the basketball game is a training process that always leads to technique without paying attention to the training process, which leads to playing comprehension. As a result, the training process is monotonous and the athletes are unable to be creative while playing. Often the coaches provide instructions that refer to basic techniques so that many athletes do not understand the coach's strategy. The results of other studies revealed that there are some basketball trainers who ignore the tactical aspects of training [19]. The tendency of coaches is to focus on prioritizing technical skills, even though tactical skills can train decision making in various situations during a match [20]. Therefore, a playing comprehension model is needed to make athletes understand what the coach instructs. Through this playing comprehension model, coaches can help trainers get information, create ideas, develop skills, find the ways of thinking and express ideas while playing.

\section{Methods}

The method used in this study was an experimental method with a one-group pretest posttest design for 8 meetings held in 2 months. The population of this research was basketball athletes aged 11-14 years in the basketball club, Bandung regency. The sample of the study was 20 high-ability athletes. Next, the instrument used was a basketball playing skill test using the Game Performance Assessment Instrument. There are seven components of a GPAI assessment according to [21]. They are 1) returning to home base, which refers to a player who returns to his original position after he has made a certain skill movement, 2) adjusting, which refers to the movement of a player when attacking or defending according to the demands of the game situation, 3) decision making, which is done by every player, at any time in any situation, 4) carrying out certain skills (skill execution) after making a decision, then a player carries out the various skills he chooses, 5) providing support with a ball-free motion in a position to receive the bait or throw, 6) overlaying a friend (cover), this movement carried out to layer the defense behind a teammate who is trying to block the opponent's attack rate or who is moving towards the opponent who controls the ball, 7) maintaining or follow the opponent's movements (guard or mark) to restrain the opponent's movement rate. Of the seven assessments taken by the researcher, the focus was only on the three components that were used as the assessment of this study, including carrying out skills (skill execution), decision making (decision making), and providing support (support)[20]. Analysis of research data was carried out to solve the research topic of this problem. The first was to calculate the average value of the standardized sample group. The second was to know the standard deviation. The third was to test the normality of the data. The fourth was to test homogeneity. The last was to test hypotheses. When the data was found normally distributed and homogeneous, a parametric statistical test was then carried out using the paired t-test. 
Table 1. Pre-test, post-test, and standard deviation

\begin{tabular}{|c|c|c|c|c|c|}
\hline Experimental Group & $\mathrm{N}$ & $X X \pm \mathrm{sd}$ & $\alpha$ & $\mathrm{t}$ calculation & $\mathrm{t}$ table \\
\cline { 1 - 3 } Pre-test & 12 & $0,658 \pm 0,0795$ & \multirow{2}{*}{ Elferinkhlm 12). 0,05} & 17 & 2,201 \\
\hline Post-test & 12 & $0,828 \pm 0,0490$ & & & \\
\hline
\end{tabular}

\section{Results}

The results of the study showed differences in development. The results of the treatments are described in Table 1.

Table 1 shows that the $\mathrm{t}$ value is 17 , $\mathrm{t}$-table is $\alpha=0.05$ with $\mathrm{df}=11$, and the value is 2.201 . Because the value of $\mathrm{t}$ count $=17>\mathrm{t}$ table 2.201, it concludes that Ho is rejected. Therefore, it indicates that there is an effect of the application of playing comprehension model on improving basketball playing skills.

\section{Discussion}

The results of this study show that there is an effect of applying playing comprehension model on improving basketball playing skills. The results of playing comprehension training were obtained from a training process that was designed and planned by looking at the performance during the match. According to research, athlete's performance in sports is the result of training tasks, environmental factors, and the athlete's own talents. Through the process of identifying and developing talent in sports, the performance of talented athletes aged 11-14 years, including technical and tactical skills, increases along with the physical abilities of these athletes [21, 22]. Furthermore, there are other research results which reveal that the performance of an athlete will be seen in the technical skills of an athlete, but the accuracy of the results of the movement depends on the results of decisions when making the required movements, thus they must separately measure the athlete's performance from a technical and tactical perspective [23].

At the level of the training process, players must be trained regarding decision making, supporting teammates, as well as displaying their abilities. Therefore, technical and tactical planning does not only depend on the coach's instinct, but is also influenced by the characteristics of the players [24]. This is reinforced by other research stating that not only technical skills, knowledge of the use of tactics must also be learned [25]. This means that when the game situation is in progress, a player's technical abilities can be used through game tactics, so that goals are achieved [26,27]. Determining good performance in games cannot be separated from the quality of decisions and the implementation of motor skills [28]. Basketball players automatically know what to do, make the right decisions at any given moment, and do the right things to achieve game goals [29].
The concept of playing comprehension is a concept that will analyze each team based on the results of the performance of each athlete in making decisions, demonstrating abilities, and supporting teammates. This is closely related to understanding strategy and tactics at play. The concept of understanding play is designing a focus on developing tactics and making decisions when performing performance in games [30]. In addition, basketball is a game that requires cooperation from each team member. Tactically, the effort to support the ball carrier, making decisions in certain situations, having to decide whether to shoot the ball into the opponent's basket or pass the ball to the other, are highly complex performance patterns. The high level of collaboration between technique and tactics can develop high quality play [31]. Collaboration techniques and tactics can be analyzed through performance in a match. How all the techniques mastered by athletes can be displayed through tactics and strategies under pressure from the opponent.

In fact, when treatment is given, many athletes encounter tactical problems in a variety of situations, that athletes are trained to know what situations are happening in the game and know how to solve these situations. Some of the situations that often occur are:

The game in the form of a game resembles a game situation that is often encountered in real games as an athlete's task. In these situations, a lot of the athlete holds the athlete responsible for completing his / her movement tasks by solving problems, such as what should I do if the defender does a tight man to guard man? That way, the athlete tries to solve the problem to get through tight guard.

When given a form of play, an individual's willingness to get the best results appears by trying to make the right decisions while the game is in progress.

Communication begins between athletes when entering a more complex form of group play, resulting in communication, confidence, and trust in friends to solve problems in these situations.

Athletes try to express how they should deal with situations in the game, for example, what to do if a friend is free from guard? Hence, the athlete tries to pass it to his friend so that the pass is carried out correctly (skill execution).

Athletes dare to carry out skills (skill execution) as a result of decision making. For example, students do a movement without the ball to escape from guard to create a pass (support). When in a free from guard position, the athlete gets a pass and decides to take a shot at the basket. Then, the athlete boxes out when a player takes a shot at the basket. 


\section{Conclusions}

The playing comprehension model shows a significant change in improving basketball playing skills. The improvement was seen from the better final test scores than the initial tests performed. Thus, the researchers concluded that the playing comprehension model had a significant effect on basketball playing skills, namely decision making, skill execution, guarding and following the opponent's movements (guard or mark), and support.

\section{Acknowledgement}

I would like to express my deepest gratitude to Professor Saputra, Professor Nurihsan, and Professor Kusnaedi, my research adviser, for their patient guidance, enthusiastic encouragement, and useful criticism for this research.

\section{REFERENCES}

[1] Elder, G. H., \& Shanahan, M. J. (2007). The Life Course and Human Development. Handbook of Child Psychology. doi: 10.1002/9780470147658. chpsy0112

[2] Baltes, P. B., Lindenberger, U., \& Staudinger, U. M. (2007). Life Span Theory in Developmental Psychology. Handbook of Child Psychology. doi:10.1002/9780470147658.chpsy0 111

[3] Gallahue \& Ozmun (1998). Understanding Motor Development. Mc. Graw Hill Company. International Editions.

[4] Haywood (1993) Life Span Motor Development. Human Kinetics Publisher. Second Edition. ISBN:0-87322-483-3

[5] AzyyAti, M. N., FArizA, M. S., \& Salasiah Hanin, H. (2013). Ciri-ciri Remaja Berisiko: Kajian literatur Risk Teens Features: A Literature Review. Islamiyyat, 35(1), 111-119.

[6] Diananda, A. (2019). Psikologi Remaja Dan Permasalahannya. Journal ISTIGHNA, 1(1), 116-133. https://doi.org/10.33853/istighna.v1i1.20

[7] Strong, W. B., Malina, R. M., Blimkie, C. J. R., Daniels, S. R., Dishman, R. K., Gutin, B., Hergenroeder, A. C., Must, A., Nixon, P. A., Pivarnik, J. M., Rowland, T., Trost, S., \& Trudeau, F. (2005). Evidence based physical activity for school-age youth. Journal of Pediatrics, 146(6), 732-737. https://doi.org/10.1016/j.jpeds.2005.01.055

[8] Tammelin, T., Näyhä, S., Hills, A. P., \& Järvelin, M. R. (2003). Adolescent participation in sports and adult physical activity. American Journal of Preventive Medicine, 24(1), 22-28. https://doi.org/10.1016/S0749-3797(02)0057 $5-5$

[9] Hardy, L. L., King, L., Farrell, L., Macniven, R., \& Howlett, S. (2010). Fundamental movement skills among Australian preschool children. Journal of Science and Medicine in
Sport, 13(5), 503-508. https://doi.org/10.1016/j.jsams.200 9.05.010

[10] Holfelder, B., \& Schott, N. (2014). Relationship of fundamental movement skills and physical activity in children and adolescents: A systematic review. Psychology of Sport and Exercise, 15(4), 382-391. https://doi.org/10.1016/j.psychsport.2014.03.005

[11] Smith. (2003). A Framework for Understanding the Training Process Leading to Elite Performance Sports Med 2003; 33 (15): 1103-1126 0112-1642/03/0015

[12] Balyi, I, \& Hamilton, A. (2004). Long-Term Athlete Development: Trainability in Childhood and Adolescence. Windows of Opportunity. Optimal Trainability. Training, 16(1), 1-6.

[13] Leite, N., \& Sampaio, J. (2012). Long-term athletic development across different age groups and gender from portuguese basketball players. International Journal of Sports Science and Coaching, 7(2), 285-300. https://doi.org/10.1260/17479541.7.2.285

[14] Baker, J., Cobley, S., \& Fraser-Thomas, J. (2009). What do we know about early sport specialization? Not much! High Ability Studies, 20(1), 77-89. https://doi.org/10.1080/1359 8130902860507

[15] Hoffman Jay R.; Fry, Andrew C.; Howard, Robert; Maresh, Carl M.; Kraemer, William J. (1991). Strength, Speed, and Endurance Changes During the Course of a Division I Basketball Season. Journal of Applied Sport Science Research. Volume 5.

[16] Carvalho, H. M., Coelho-E-Silva, M. J., Gonçalves, C. E., Philippaerts, R. M., Castagna, C., \& Malina, R. M. (2011). Age-related variation of anaerobic power after controlling for size and maturation in adolescent basketball players. Annals of Human Biology, 38(6), 721-727. https://doi.org/10.3109/03014460.2011.613852

[17] Guimarães, E., Baxter-Jones, A., Maia, J., Fonseca, P., Santos, A., Santos, E., Tavares, F., \& Janeira, M. (2019). The Roles of Growth, Maturation, Physical Fitness, and Technical Skills on Selection for a Portuguese Under-14 Years Basketball Team. Sports, 7(3), 61. https://doi.org/10.3390/sports7030061

[18] Csataljay, G., Donoghue, P. O., Hughes, M., \& Dancs, H. (2017). Performance indicators that distinguish winning and losing teams in basketball, 8668(June).

[19] McGee, Kathy (2007). Coaching Basketball Technical and Tactical Skill. ISBN- 13:978-0-7360-8533-5

[20] Budi Aryanto, Awan Hariono, Cukup Pahalawidi (2021). The Validity and Reliability Construct Skills Assessments Skill in Korfball by Using Exploratory Factor Analysis and Confirmatory Factor Analysis. International Journal of Human Movement and Sports Sciences. 9(2): 231-235, 2021. DOI: 10.13189/saj.2021.090210

[21] Oleksii Tymoshenko, et.all (2021). Exercise Machines in Speed and Coordination Development among Students Playing Basketball. International Journal of Human Movement and Sports Sciences 9(2): 347-355, 2021. DOI: 10.13189/saj.2021.090224

[22] Van Mullem, P., \& Brunner, D. (2013). Developing a Successful Coaching Philosophy: A Step-by-Step 
Approach. Strategies, 26(3), 29-34.https://doi.org/10.1080 /08924562.2013.779873

[23] Oslin, J., Mitchell, S \& Griffin, L. (1998). Teaching Sport Concept and Skills. USA.

[24] Elferink-Gemser, Chris Visscher, Koen A. P. M. Lemmink \& Theo Mulder (2007) Multidimensional performance characteristics and standard of performance in talented youth field hockey players: A longitudinal study, Journal of Sports Sciences, 25:4, 481 - 489,DOI:10.1080/0264041060 0719945

[25] Kolman, Tamara Kramer, Marije T. ElferinkGemser, Barbara C. H. Huijgen \& Chris Visscher (2019): Technical and tactical skills related to performance levels in tennis: A systematic review, Journal of Sports Sciences, DOI: 10.1080/02640414.2018.1483699

[26] Cañadas, J. Sergio Ibáñez \& Nuno Leite (2015) A novice coach's planning of the technical and tactical content of youth basketball training: A case study, International Journal of Performance Analysis in Sport, 15:2, 572-587 To link to this article: http://dx.doi.org/10.1080/24748668.20 15.11868815

[27] McMorris, T. (1998). Teaching Games for Understanding: Its Contribution to the Knowledge of Skill Acquisition from a Motor Learning Perspective. European Journal of Physical Education, 3(1), 65-74. https://doi.org/10.1080/1 740898980030106
[28] Gabbett, T., Georgieff, B., \& Domrow, N. (2007). The use of physiological, anthropometric, and skill data to predict selection in a talent-identified junior volleyball squad. Journal of Sports Sciences, 25(12), 1337-1344. doi:10.1080/02640410601188777

[29] Avugos, S., Bar-Eli, M., Ritov, I., \& Sher, E. (2013). The elusive reality of efficacy-performance cycles in basketball shooting: An analysis of players' performance under invariant conditions. International Journal of Sport and Exercise Psychology, 11(2), 184-202. doi:10.1080/161219 $7 x .2013 .773661$

[30] Turner, A., \& Martinek, T. J. (2012). Teaching for Understanding: A Model for Improving Decision Making During Game Play. Quest, 47(1), 44-63. doi:10.1080/00336297.1995.10484144

[31] Tavares, F. (2017). The defensive dimension in basketball analysis of the cinematic pattern of the defensive slide, the declarative knowledge and technical and tactical structures, 8668(May).

[32] Chouinard, A. D. (2007). Contemporary Models Of Sport And Games Education : AN

[33] Bazanov B, Võhandu P, Haljand R (2017) Factors influencing the teamwork intensity in basketball. International Journal of Performance Analysis in Sport (2006) 6(2)88-96 DOI: 10.1080/24748668.2006.11868375 